\title{
Identification of salivary basic proline-rich proteins as receptors for Candida albicans adhesion
}

\author{
Justin M. O'Sullivan, ${ }^{1}$ Richard D. Cannon, ${ }^{1}$ Patrick A. Sullivan ${ }^{2}$ \\ and Howard F. Jenkinson ${ }^{1}$
}

\begin{abstract}
Author for correspondence: Richard D. Cannon. Tel: +64 3479 7081. Fax: +64 34790673.
\end{abstract} e-mail: richard.cannon@stonebow.otago.ac.nz

1 Department of Oral Biology and Oral Pathology, University of Otago, PO Box 647, Dunedin, New Zealand

2 Department of Biochemistry, Massey University, Palmerston North, New Zealand

\begin{abstract}
The adherence of Candida albicans cells to oral surfaces is believed to be an important step in the development of oral candidosis. Electrophoretically separated parotid salivary proteins were transferred to nitrocellulose membranes and incubated with [ ${ }^{35} 5$ ]methionine-radiolabelled C. albicans cells in a cell overlay adherence assay. A subset of four proteins with apparent molecular masses of 17, 20, 24 and $27 \mathrm{kDa}$ (designated bands A-D) acted as receptors for cells of C. albicans ATCC 10261 and four clinical C. albicans isolates, in overlay assays. The $\mathbf{N}$-terminal amino acid sequence of bands $A-D$ indicated that these proteins were members of the basic proline-rich protein (bPRP) family. Digestion of protein A with endoproteinase Glu-C resulted in a single band (designated AP) detected by Coomassie blue staining after SDSPAGE. This band was not bound by $C$. albicans cells in overlay assays and comprised two fragments, designated ApN and ApC. These fragments had Nterminal sequences corresponding to the $\mathrm{N}$-terminal and post endoproteinase Glu-C cleavage site sequences of bPRP IB-6 and had molecular masses of 6189 and $4261 \mathrm{Da}$ as determined by mass spectrometry. Thus intact bPRP IB-6, and other bPRPs, may act as receptors for $C$. albicans adhesion.
\end{abstract}

Keywords: Candida albicans, basic proline-rich proteins (bPRPs), adherence, parotid salivary proteins

\section{INTRODUCTION}

The yeast Candida albicans forms part of the normal human oral microbial flora and can be isolated from the mouths of $20-40 \%$ of healthy individuals (Odds, 1988). Under conditions of host immunosuppression, $C$. albicans can cause a variety of mucosal infections, including pseudomembranous candidosis, erythematous candidosis, hyperplastic candidosis, Candida-associated denture stomatitis and Candida-associated angular cheilitis (Odds, 1988; Scully et al., 1994). Indeed, oral candidosis is a prognostic indicator for AIDS, with $33-50 \%$ of HIV-seropositive and AIDS patients developing oral candidosis, which can lead to serious oesophageal infections (Samaranayake \& Holmstrop, 1989; Samaranayake, 1992).

Oral surfaces are coated with salivary pellicles formed

Abbreviations: bPRP, basic proline-rich protein; PRG, proline-rich glycoprotein; PRP, proline-rich protein. by the selective adsorption of components from whole saliva and from other minor secretions, e.g. serum exudate (Sönju et al., 1974). Pellicle maturation involves additional intermolecular protein interactions and enzymic modification, such as the covalent linking of proline-rich proteins (PRPs) to buccal epithelial cells (Bradway et al., 1992). Proteinaceous pellicles provide a range of immobilized receptors for microbial adhesion (Jensen et al., 1992). An initial step in the establishment of oral candidosis involves the adhesion of yeast cells to saliva-coated host tissues and so it is important to study the interaction between Candida cells and components of salivary pellicles. An understanding of the structure and function of the molecules involved in this interaction may enable the development of methods to prevent the adherence of Candida, or promote the clearance of Candida cells from the oral cavity.

C. albicans cells bind to a number of receptors, including fibronectin (Skerl et al., 1984) and the $\mathrm{H}$ sugar sequence found on all blood group substances of the $\mathrm{ABO}[\mathrm{H}]$ system (Brassart et al., 1991). Adherence of C. albicans 
cells to a single component of human whole saliva, provisionally identified as low-molecular-mass mucin MG2, and to rat submandibular gland (RSMG) mucin (Hoffman \& Haidaris, 1993) has also been demonstrated. However, it was later shown that purified mucins did not promote the adhesion of C. albicans to polymethylmethacrylate (Edgerton et al., 1993) and that the C. albicans-binding component of RSMG was in fact a proteoglycan (Hoffman \& Haidaris, 1994). Similarly, we have previously demonstrated that parotid saliva fractions containing mucins did not promote the adherence of $C$. albicans cells to hydroxylapatite beads (Cannon et al., 1995). C. albicans cells were found to adhere to fractions of saliva containing PRPs, which have also been shown to promote adhesion of Streptococcus gordonii to apatitic surfaces (Gibbons et al., 1991). The objective of this study was to further characterize components from parotid saliva that act as receptors for $C$. albicans adherence.

\section{METHODS}

Yeast strains, media and culture conditions. The following $C$. albicans strains were used in this study: ATCC 10261; I1 (hp11an; Schmid et al., 1990); I17 (hp50an; Schmid et al., 1995); I33 (HMHc4; Schmid et al., 1990); and I44 (sw-17c; Schmid et al., 1995). C. albicans cells were grown in glucose salts biotin medium (GSB; Holmes \& Shepherd, 1988) at $30^{\circ} \mathrm{C}$ with shaking (250 r.p.m.). Radiolabelled C. albicans cells were prepared by inoculating GSB $(40 \mathrm{ml})$, containing $0.76 \mu \mathrm{Ci}(28.0 \mathrm{kBq})\left[{ }^{35} \mathrm{~S}\right]$ methionine $\mathrm{ml}^{-1}$, with stationary phase cells $\left(1.1 \times 10^{6}\right.$ cells $\left.\mathrm{ml}^{-1}\right)$ and incubating at $30^{\circ} \mathrm{C}$ until the cell density reached $2.2 \times 10^{7}$ cells $\mathrm{ml}^{-1}$. Cells were harvested by centrifugation $(6000 \mathrm{~g}, 15 \mathrm{~min})$ and washed twice with $4 \mathrm{ml} \mathrm{KCl}$ buffer $\left(2 \mathrm{mM} \mathrm{KH}_{2} \mathrm{PO}_{4}, 2 \mathrm{mM} \mathrm{K}_{2} \mathrm{HPO}_{4}, 5 \mathrm{mM}\right.$ $\mathrm{KCl}, 1 \mathrm{mM} \mathrm{CaCl}, \mathrm{pH} 6.5$ ) before being resuspended in $\mathrm{KCl}$ buffer at a concentration of $2.6 \times 10^{8}$ cells $\mathrm{ml}^{-1}$. $\left.{ }^{35} \mathrm{~S}\right]$ Methionine uptake from the medium varied between 80 and $96 \%$, with a mean of $88.8 \pm 6.6 \%$ (SD). The specific radioactivity of cells was calculated by measuring the radioactivity of a cell suspension and varied between 13 and 38 cells (c.p.m.) $)^{-1}$ with a mean value of $17 \pm 5 \cdot 2$ cells (c.p.m.) $)^{-1}$.

Collection of parotid saliva. Stimulated parotid saliva $(10 \mathrm{ml})$ was collected from donors, using a modified CarlsonCrittenden device (Shannon et al., 1962), and stored on ice. Proteinase inhibitors were added to final concentrations of $1 \mathrm{mM}$ PMSF, $10 \mathrm{mM}$ bisulphite, $2 \mathrm{mM}$ benzamidine. $\mathrm{HCl}$, $2.9 \mathrm{mM}$ pepstatin $A$ and $0.3 \mathrm{mM}$ aprotinin. The parotid saliva from six donors, three male and three female with a mean age of 37.5 years, was pooled and clarified by centrifugation (12000 g, $4{ }^{\circ} \mathrm{C}, 15 \mathrm{~min}$ ).

Column fractionation of parotid saliva. Pooled parotid saliva $(60 \mathrm{ml})$ was dialysed against water $(18 \mathrm{~h})$, lyophilized and resuspended in $10 \mathrm{ml}$ Tris/ $\mathrm{NaCl}$ elution buffer $(20 \mathrm{mM}$ Tris/ $\mathrm{HCl}, \mathrm{pH} 8.0 ; 0.5 \mathrm{M} \mathrm{NaCl}$ ). The sample (92 mg protein) was then loaded onto a Sephacryl S200 (fractionation range from 5 to $250 \mathrm{kDa}$ ) chromatography column (XK 26/100; Pharmacia) and eluted with Tris/ $\mathrm{NaCl}$ buffer $\left(0.17 \mathrm{ml} \mathrm{min}^{-1}\right.$; Strömberg et al., 1992). Column eluate was monitored at $226 \mathrm{~nm}$ (2138 Uvicord S; LKB), fractions (4 ml) were collected, and the peak fractions were pooled.

Hydroxylapatite-bead adhesion assay. The attachment of radiolabelled C. albicans cells to parotid-saliva-coated hydroxylapatite beads ( $20 \mathrm{mg}$; Phase Sep) was measured as described by Cannon et al. (1995).

SDSPAGE and electroblotting. SDS-PAGE was performed according to the method of Laemmli (1970) at $15 \mathrm{~V} \mathrm{~cm}^{-1}$ and $16^{\circ} \mathrm{C}$. The apparent molecular mass of proteins was estimated using prestained protein markers $(2 \cdot 9-44 \mathrm{kDa}$ and $14 \cdot 7-$ $200 \mathrm{kDa}$; Gibco-BRL). Sample protein concentrations were determined using a modified Bradford assay (Bio-Rad). Proteins were electroblotted (Towbin et al., 1979) onto nitrocellulose membranes (Hybond-C) for use in blot overlays or onto PVDF membrane (Immobilon-P) for N-terminal amino acid sequencing.

Blot overlay. A modification of the method of Prakobphol $e t$ al. (1987) was used. Western-blotted proteins on nitrocellulose membranes were visualized by staining them with $0.2 \%$ Ponceau $\mathrm{S}$ in $1 \%(\mathrm{v} / \mathrm{v})$ acetic acid for $5 \mathrm{~min}$, followed by four washes with $1 \%(\mathrm{v} / \mathrm{v})$ acetic acid. Ponceau $S$ binds reversibly to protein and is reported not to alter epitopes on the immobilized proteins (Klein et al., 1995). The membranes were destained with two washes $\left(30 \mathrm{~min}, 20^{\circ} \mathrm{C}\right)$ of PBS $\langle 8 \cdot 5 \mathrm{~g}$ $\left.\mathrm{NaCl} l^{-1}, 0.3 \mathrm{~g} \mathrm{KH}_{2} \mathrm{PO}_{4} \mathrm{l}^{-1}, 0.6 \mathrm{~g} \mathrm{Na}_{2} \mathrm{HPO}_{4} \mathrm{l}^{-1}, \mathrm{pH} 7.5\right)$ and blocked with $5 \%(\mathrm{w} / \mathrm{v})$ BSA in $\mathrm{KCl}$ buffer $\left(2 \mathrm{~h}, 20^{\circ} \mathrm{C}\right)$. Western blots were incubated with radiolabelled C. albicans cells $\left[30 \mathrm{ml} ; 1 \cdot 1 \times 10^{7}\right.$ cells $\left.(\mathrm{ml} \mathrm{KCl} \text { buffer })^{-1}\right]$ for $18 \mathrm{~h}$ at $4{ }^{\circ} \mathrm{C}$ with reciprocal shaking $\left(70 \mathrm{~min}^{-1}\right)$. Membranes were washed four times in PBS $/ 0.1 \%$ Tween 20 to remove nonspecifically bound C. albicans cells and air-dried prior to exposure to $\mathrm{X}$-ray film.

Protein analyses. Solid-phase protein samples on PVDF membranes were $\mathrm{N}$-terminally microsequenced by automated Edman degradation (Hubbard, 1995).

Protease digestion was performed by the method of Cleveland et al. (1977). Proteins were separated on $16 \%$ polyacrylamide gels, stained with Coomassie blue, and portions of the gel containing specific bands were excised. These proteins were digested with $0 \cdot 06-0 \cdot 6$ units endoproteinase Glu-C (sequencing grade; Promega). Digestion was performed within a polyacrylamide stacking gel, with no current for periods of 10 or $20 \mathrm{~min}$, and the products were then separated by electrophoresis through a $16 \%$ polyacrylamide gel $\left(25 \mathrm{~V} \mathrm{~cm}^{-1}\right.$, $22^{\circ} \mathrm{C}$ ).

Proteins were prepared for mass spectrometry (MS) by extraction from nitrocellulose with trifluoroacetic acid (TFA) and acetonitrile using the method of Harrington (1990). Samples were freeze-dried and resuspended in 5-10 $\mu \mathrm{l} 0.1 \%$ TFA, to a concentration of 5-10 $\mathrm{pmol} \mathrm{\mu l}^{-1}$. Matrix-assisted laser desorption/ionization time-of-flight (MALDI-TOF) MS was performed using a Finnigan Lasermat 2000 MALDI-TOF mass analyser. The mass spectrometer was calibrated against the $\alpha$-cyanohydroxycinnamic acid matrix peak at $379 \cdot 4 \mathrm{Da}$.

\section{RESULTS}

\section{Binding of C. albicans cells to electrophoretically separated parotid saliva proteins}

Human parotid salivary proteins were separated by SDS-PAGE, electroblotted onto nitrocellulose membranes and incubated with radiolabelled Candida cells. C. albicans ATCC 10261 cells bound reproducibly to 16 proteins with molecular masses of between 17 and $63 \mathrm{kDa}$. There were a number of immobilized protein bands which did not stain intensely with Ponceau S but 
(a)

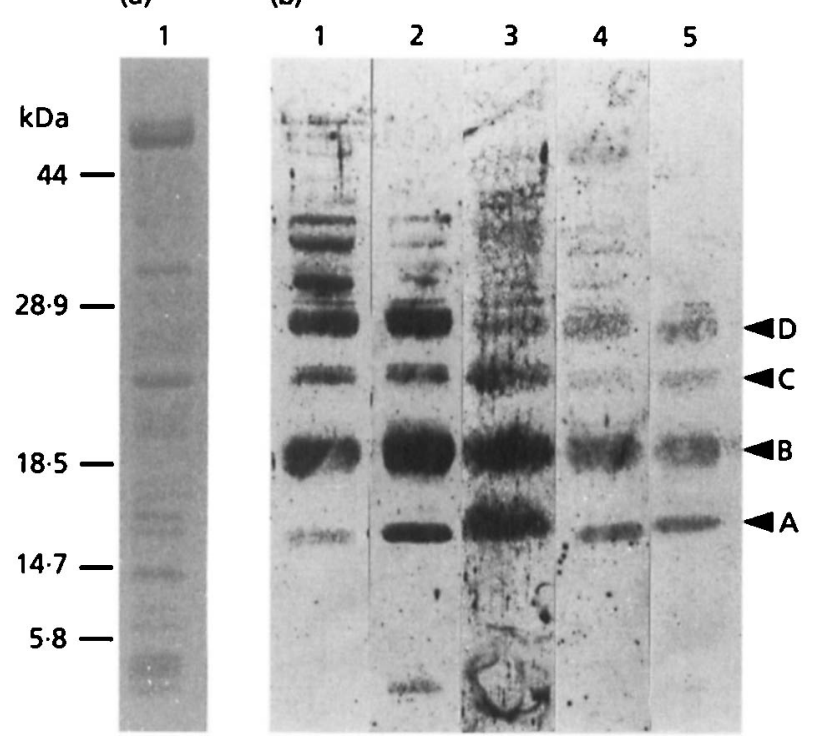

Table 1. Adherence of $C$. albicans strains to salivacoated hydroxylapatite beads

Yeast cells were grown in GSB at $30^{\circ} \mathrm{C}$. Results are the means of at least six determinations carried out on a representative batch of cells. The number of input cells was $2 \cdot 40 \pm 0.39 \times 10^{6}$ (mean $\pm \mathrm{sD})$.

\begin{tabular}{|lcc|}
\hline $\begin{array}{l}\text { C. albicans } \\
\text { strain }\end{array}$ & $\begin{array}{c}\mathbf{1 0}^{-\mathbf{5}} \times \text { No. of } \\
\text { cells adhering } \\
( \pm \mathrm{SD})\end{array}$ & $\begin{array}{c}\text { Adherence relative to } \\
\text { C. albicans ATCC } \\
\mathbf{1 0 2 6 1}(\%)\end{array}$ \\
\hline ATCC 10261 & $3.66 \pm 0.59$ & 100 \\
I1 & $5.07 \pm 0.42$ & $112.5 \pm 9$ \\
I17 & $1.95 \pm 0.42$ & $53.4 \pm 1 \cdot 15$ \\
I33 & $0.53 \pm 0.07$ & $13.8 \pm 1 \cdot 6$ \\
I44 & $2.34 \pm 0.38$ & $87.5 \pm 13.8$ \\
\hline
\end{tabular}

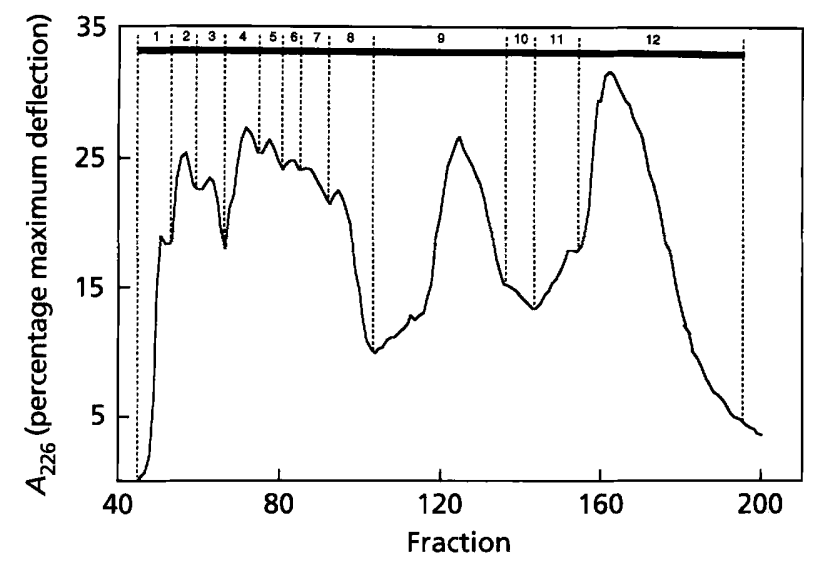

Fig. 2. Preparative fractionation of parotid saliva on a Sephacryl S200 column. The elution profile (-) is expressed as the percentage maximum $A_{226}$ deflection; the thick bar denotes pooled fractions. Pools $1-3$ contain the high-molecular-mass components and PRGs, pools 4 and 5 contain PRPs, pools 7 and 8 contain unknown components, pool 9 contains statherin and pool 12 contains mainly $\alpha$-amylase (Strömberg et al., 1992).

cells (Table 1). The proportion of strain I44 cells binding to beads was slightly less than that for ATCC 10261 and the proportion of adherent cells was markedly decreased for strains I17 and I33. Interestingly, the amount of cell binding to proteins on the overlay assay (Fig. 1) correlated with the adherence measured using the salivacoated hydroxylapatite-bead adhesion assay. All strains were labelled with $\left[{ }^{35} \mathrm{~S}\right]$ methionine to the same specific radioactivity.

\section{Fractionation of parotid saliva}

Parotid saliva was fractionated by column chromatography (Fig. 2) using a modification of the method of Strömberg et al. (1992). Fractions containing protein peaks, judged by the $A_{226}$, were pooled (Fig. 2). The
In the hydroxylapatite-bead adhesion assay, a greater proportion of clinical isolate I1 cells bound to salivacoated hydroxylapatite beads than did ATCC 10261 
(a)

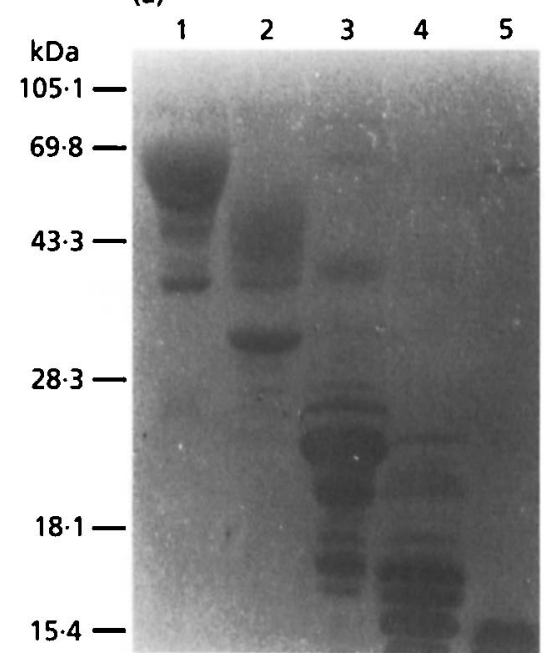

(b)

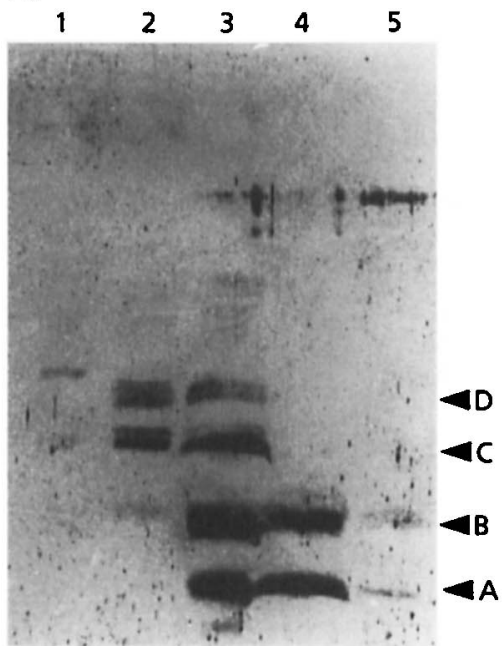

Fig. 3. Binding of C. albicans ATCC 10261 cells to fractionated parotid salivary proteins. Proteins in fraction pools (Fig. 2) were separated on a $12.5 \%$ polyacrylamide gel and electroblotted onto a nitrocellulose membrane. The protein loading was $15 \mu \mathrm{g}$ protein per lane. (a) Ponceau-S-stained nitrocellulose blot. Lanes $1-5$ are pools 1-5, respectively. (b) Autoradiogram of the membrane in (a) incubated with $C$. albicans ATCC 10261 cells. Lanes are the same as (a). Arrowheads indicate the subset of proteins to which all Candida strains tested bound. proteins present in these fraction pools were concentrated by dialysis against $\mathrm{NH}_{4} \mathrm{HCO}_{3}$, lyophilized and resuspended in $\mathrm{KCl}$ buffer. The protein-banding pattern of the pooled parotid salivary proteins after SDS-PAGE and Ponceau S staining was not affected by concentrating the pools. Pools 1-4 each contained several proteins with a wide range of molecular masses (Fig. 3). This may indicate that under the nondenaturing chromatography conditions, proteins formed heterocomplexes which were subsequently resolved into component proteins by SDS-PAGE. Comparisons of the molecular masses of the electrophoretically separated proteins suggested that pools $1-4$ contained proline-rich glycoproteins (PRGs) and PRPs (Strömberg et al., 1992). Hydroxylapatite-bead adhesion assays confirmed that pools 1-4 promoted the highest levels of C. albicans adherence. Blot overlay assays carried out on the fraction pools indicated that most of the binding of $C$. albicans ATCC 10261 cells occurred to proteins present in pools 2, 3 and 4 (Fig. 3). The C. albicans cells bound to the same subset of proteins identified in overlay assays using unfractionated saliva (Fig. 1). Pools 6-12 contained very few proteins and gave a similar banding pattern in the overlay assay to pool 5 , except that there was no binding to bands A or B (data not shown).

\section{Characterization of bands A, B, C and D}

Bands A and B were electrophoretically separated from pool 3 and bands $C$ and D were separated from parotid saliva. They were then transferred to PVDF membrane (Towbin et al., 1979) and excised. Approximately 180 pmol band A and band B was sequenced, and each was found to have the same $\mathrm{N}$-terminal amino acid sequence, $\mathrm{NH}_{3}$-SPPGKPQGPPPQGGNQPQGP, with no indication of a contaminating sequence. Bands $\mathrm{C}$ and $\mathrm{D}$ had the same $\mathrm{N}$-terminal sequence, $\mathrm{NH}_{3}$-SPPGKPQG. A comparison of the $\mathrm{N}$-terminal sequence of bands $\mathrm{A}$ and $B$ with protein databases resulted in five matches
Table 2. Proteins with the same $\mathrm{N}$-terminal amino acid sequence as bands $A$ and $B$

Proteins that showed $100 \%$ sequence similarity to $\mathrm{A}$ and $\mathrm{B}$ over the initial $20 \mathrm{~N}$-terminal amino acids are listed. Matches were determined using the BLAST algorithm (Altschul et al., 1990).

\begin{tabular}{|lrc|}
\hline Protein identity & $\begin{array}{c}\text { Predicted } \\
\text { molecular } \\
\text { mass* } \\
\text { (Da) }\end{array}$ & $\begin{array}{c}\text { Predicted } \\
\text { endoproteinase } \\
\text { Glu-C digestion } \\
\text { products (Da) }\end{array}$ \\
\hline IB-6 (Kauffman et al., 1986) & 11518 & $7274 ; 4262$ \\
IB-7 (Kauffman et al., 1991) & 5770 & $5285 ; 503$ \\
IB-8a (Kauffman et al., 1991) & 12430 & $5295 ; 5285 ; 1886$ \\
IB-8c (Kauffman et al., 1991) & 5843 & 5843 \\
IB-9 (Kauffman et al., 1982) & 6025 & $5313 ; 730$ \\
\hline
\end{tabular}

* Molecular mass was calculated using the GeneJockey program (Biosoft; Cambridge).

with $100 \%$ similarity over the 20 amino acids (Table 2). All matches were with human parotid salivary nonglycosylated bPRPs. As these proteins (IB-6, IB-7, IB-8a, IB-8c and IB-9) each have the same $\mathrm{N}$-terminal sequence (Kauffman et al., 1991), identification of the proteins in bands $\mathrm{A}, \mathrm{B}, \mathrm{C}$ and $\mathrm{D}$ beyond being members of the nonglycosylated bPRP family could not be made at the level of N-terminal amino acid sequence.

Band A was chosen for further analysis as it was the smallest member of the parotid salivary protein subset to which C. albicans cells bound. Endoproteinase Glu-C (V8 proteinase) cleaves proteins on the carboxyl side of glutamic acid or aspartic acid residues. The predicted endoproteinase Glu-C digestion products for IB-6, IB-7, IB-8a, IB-8c and IB-9 are given in Table 2. Endoproteinase Glu-C digestion of band A produced a single 


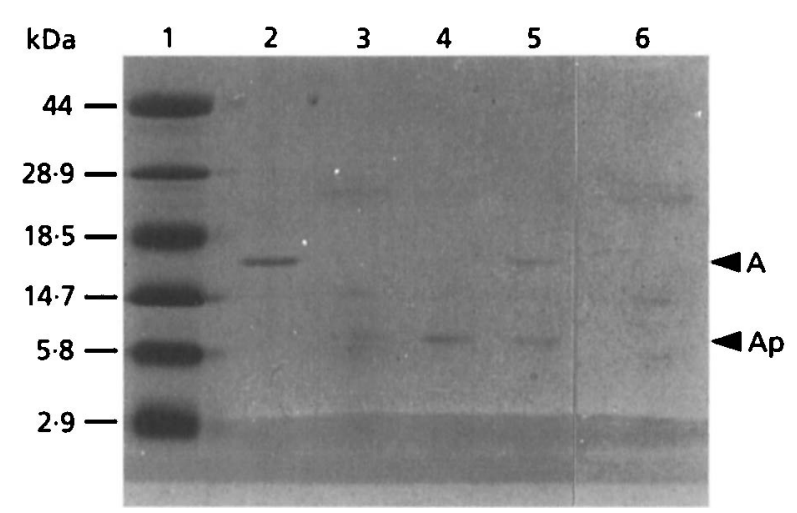

Fig. 4. Endoproteinase Glu-C digestion product of band $A$. Band $A$ was subjected to endoproteinase Glu-C digestion and then electrophoresis through a $16 \%$ polyacrylamide gel. The gel was stained with Coomassie blue by the method of Cleveland et al. (1977). Lanes: 1, low-molecular-mass markers; 2 , band $A ; 3$, band $A$ plus 0.6 units endoproteinase Glu-C; 4 , band $A$ plus 0.3 units endoproteinase Glu-C; 5 , band $A$ plus 0.06 units endoproteinase Glu-C; $6,0.6$ units endoproteinase Glu-C. $A$, Band $A$; $A p$, endoproteinase Glu-C digestion product of band $A$.

product band (Ap) detected by Coomassie blue staining (Fig. 4). Ap had an apparent molecular mass of $7.4 \mathrm{kDa}$, compared with an apparent molecular mass of $15 \cdot 2 \mathrm{kDa}$ for band A. Amino acid sequencing of protein band Ap indicated that there were two predominant peptides present with $\mathrm{N}$-terminal sequences SPPG and GNNP. The sequence of one peptide (designated ApN), SPPG, corresponds to the $\mathrm{N}$-terminal sequence of band $\mathrm{A}$ and other bPRPs, while the sequence of the other peptide (designated ApC), GNNP, corresponds to that which might be expected after endoproteinase Glu-C cleavage of bPRP IB-6 or IB-8a. However, endoproteinase Glu-C cleavage of IB-8a should result in three, rather than two, fragments (Table 2). The endoproteinase Glu-C digestion product (Ap) of band A did not act as a receptor for C. albicans adherence in overlay assays (Fig. 5).

MS of band Ap detected two species of masses $6189.07 \pm 6.02$ and $4261 \cdot 14 \pm 2.77 \mathrm{Da}$ (mean $\pm \mathrm{SD}$ of seven determinations). The mass of one of the species, $4261 \mathrm{Da}$, matched that expected for the C-terminal fragment of IB-6 (Table 2). The mass of the other species was $1085 \mathrm{Da}$ smaller than that expected for the $\mathrm{N}$ terminal endoproteinase Glu-C fragment of IB-6, and did not correspond to any of the cleavage products predicted for IB-6, IB-7, IB-8a, IB-8c or IB-9. The mass of the protein comprising band A could not be determined by MS.

\section{DISCUSSION}

Saliva is a complex mixture of ions, proteins, glycoproteins and polysaccharides of host and microbial origin (Gibson \& Beeley, 1994). A number of salivary proteins and glycoproteins are adsorbed onto oral surfaces to form the acquired pellicle and in so doing provide many potential receptors for microbial adhesins (Bradway et al., 1992). The objective of this study was to identify receptors in human parotid saliva for the adhesion of C. albicans.

Parotid saliva was studied because it can be obtained relatively free of microbial contaminants, and it was pooled in order to remove the effects of individual-toindividual saliva variations (Beeley et al., 1991). The overlay assay has been used in a number of attempts to identify possible salivary receptors for microbial adhesion (Prakobphol et al., 1987; Gillece-Castro et al., 1991; Murray et al., 1992; Hoffman \& Haidaris, 1993, 1994). Binding of Fusobacterium nucleatum to the low- (a)

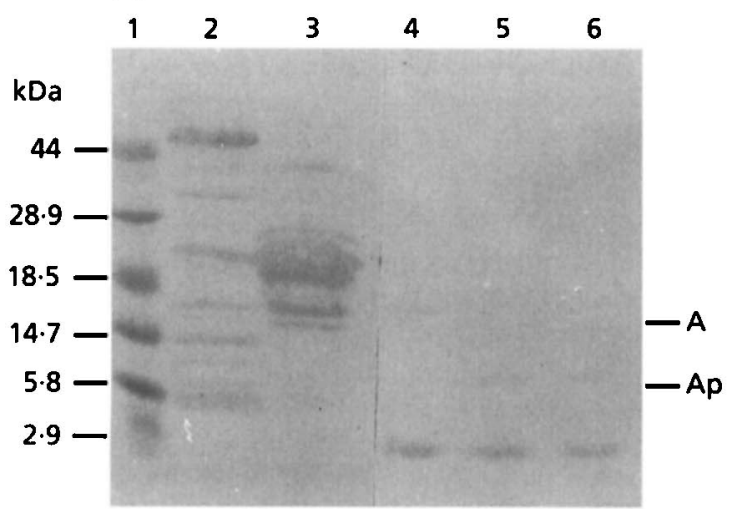

(b)

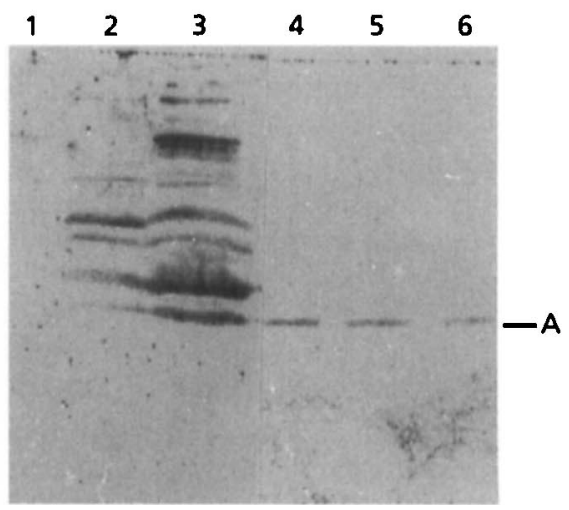

Fig. 5. Binding of C. albicans ATCC 10261 cells to band A and the endoproteinase Glu-C digestion product, Ap. Proteins were separated by electrophoresis through a $16 \%$ polyacrylamide gel and electroblotted onto a nitrocellulose membrane. (a) Ponceau-S-stained nitrocellulose membrane. Lanes: 1, low-molecular-mass markers; 2, parotid saliva $(15 \mu \mathrm{g}) ; 3$, fractionated parotid saliva pool $3(7.5 \mu \mathrm{g}) ; 4$, band $A ; 5$, band $A$ plus 0.6 units endoproteinase $G$ lu-C; 6 , band $A$ plus 0.3 units endoproteinase Glu-C. (b) Autoradiogram of the membrane in (a) probed with C. albicans ATCC 10261 cells. Lanes are the same as in (a). A, Band A; Ap, endoproteinase Glu-C digestion product of band A. 
and high-molecular-mass PRGs present in human submandibular-sublingual saliva (Prakobphol et al., 1987) has been demonstrated. Later work showed that F. nucleatum binds to the low- and high-molecular-mass PRG, via interactions with the unsubstituted lactosamine units, including the 6-antennae of the major oligosaccharide residues (Gillece-Castro et al., 1991). Murray et al. (1992) studied the binding of 16 strains of streptococci to salivary glycoproteins present in parotid and submandibular-sublingual saliva. Three strains (Streptococcus sanguis 72-40 and 804, and Streptococcus sobrinus OMZ176) bound to single components, two to mucin MG2 and one to an unidentified protein, and five strains (S. sanguis 10556, S. gordonii 10558 and G9B, and Streptococcus oralis 10557 and 72-41) bound to multiple components, including MG2, $\alpha$-amylase and PRGs.

Our previous study indicated that C. albicans bound to proteins in five separate pools of fractionated parotid saliva when adsorbed to hydroxylapatite beads (Cannon et al., 1995). Therefore, it was not surprising that radiolabelled C. albicans cells bound to several electrophoretically separated parotid saliva proteins, immobilized on nitrocellulose in the overlay assay. We have also found that C. albicans cells bound to a similar set of proteins from unstimulated human whole saliva in overlay assays (unpublished observations).

Strain-specific variation was evident in the overlay profiles; however, a subset of four proteins acted as receptors for all $C$. albicans strains tested. The fact that C. albicans bound to several parotid saliva proteins may indicate the presence of either common receptors on different parotid salivary proteins, or multiple adhesins on the surface of C. albicans. We observed that strainspecific variation in the proportion of input cells binding to parotid saliva proteins in the overlay assay correlated with the level of adhesion observed in saliva-coated hydroxylapatite-bead assays. These variations may be related to either the avidity of adherence, or the number or accessibility of adhesins on the cell surface.

C. albicans cells bound to at least four proteins with sequence homology to nonglycosylated bPRPs (bands A-D). Protease digestion of band A with endoproteinase Glu-C resulted in a single band detected by Ponceau S or Coomassie blue staining after SDS-PAGE. This band contained two protein species with molecular masses of 4261 and $6189 \mathrm{Da}$, and two predominant $\mathrm{N}$-terminal amino acid sequences. The presence in the digestion product of peptides with an $\mathrm{N}$-terminal amino acid sequence and a molecular mass predicted for the Cterminal product of endoproteinase Glu-C digestion of bPRP IB-6 indicates that the protein in band A may be bPRP IB-6. The ApN fragment appears to be a degradation product of the $\mathrm{N}$-terminal endoproteinase Glu-C fragment of IB-6 which is co-migrating with the smaller fragment. Discrepancies between the apparent molecular mass of band A and the calculated molecular mass are explained by the observation that PRPs migrate anomalously in SDS-PAGE (Anderson et al., 1982). It appears that endoproteinase Glu-C cleavage of band A results in loss of the C. albicans adhesion property. This may be due to proteolytic destruction of the adherence epitope, or conformational changes as a result of proteolysis.

The binding of C. albicans cells to immobilized bPRPs suggests that these salivary proteins may have a role in the adhesion of Candida cells in the oral cavity. C. albicans ATCC 10261 cells have been shown to adhere to both a carbohydrate moiety and proteins on the surface of immobilized $S$. gordonii cells (Holmes et al., 1995b, 1996). Pretreatment of immobilized S. gordonii NCTC 7869 cells with whole saliva enhanced C. albicans ATCC 10261 cell binding (Holmes et al., 1995a). Since $S$. gordonii NCTC 7869 and other primary colonizers of the enamel pellicle such as $S$. parasanguis and $S$. sanguis adsorb bPRPs (Heaney et al., 1992; Newman et al., 1993), it may be that these micro-organisms become coated with bPRPs and provide receptors for the binding of C. albicans. We are investigating whether C. albicans cells bind PRPs in the fluid phase. It has been shown that oral bacteria bind to adsorbed PRPs despite the presence of fluid-phase PRPs (Gibbons et al., 1991), and this may also be the case with $C$. albicans. Preliminary assays have shown that preincubation of C. albicans cells with parotid saliva did not detectably reduce the levels of PRPs.

Johnsson et al. (1993) predict that IB-6 may be capable of interacting with hydroxylapatite and thus form part of the enamel pellicle. However, mucosal surfaces are the major sites of oral colonization by $C$. albicans (Arendorf \& Walker, 1980). The enzyme transglutaminase has been shown to covalently link acidic PRPs to epithelial cells and may also be involved in the attachment of bPRPs to mucosal surfaces (Bradway $\&$ Levine, 1993). Therefore, it is possible that transglutaminase-catalysed linkage of bPRPs to epithelial cells may be another factor promoting the adherence of C. albicans cells. Alternatively, bPRPs adsorbed to bacteria already attached to epithelial cells may present adhesion receptors for $C$. albicans colonization.

\section{ACKNOWLEDGEMENTS}

Protein sequencing and MS analyses were performed by the Protein Microchemistry Facility, Department of Biochemistry, University of Otago. The authors would like to thank A. Carne, M. Hubbard and D. Carne for useful discussions and help with protein analyses. J. M. O'Sullivan was in receipt of a University of Otago Targeted Scholarship for the duration of this work.

\section{REFERENCES}

Altschul, S. F., Gish, W., Miller, W., Myers, E. W. \& Lipman, D. J. (1990). Basic local alignment search tool. J Mol Biol 215, 403-410.

Anderson, L. C., Kauffman, D. L. \& Keller, P. J. (1982). Identification of the $\mathrm{Pm}$ and $\mathrm{PmS}$ human parotid salivary proteins as basic proline-rich proteins. Biochem Genet 20, 1131-1137.

Arendorf, T. M. \& Walker, D. M. (1980). The prevalence and intraoral distribution of Candida albicans in man. Arch Oral Biol 25, $1-10$. 
Beeley, J. A., Sweeney, D., Lindsay, J. C. B., Buchanan, M. L., Sarna, L. \& Khoo, K. S. (1991). Sodium dodecyl sulphatepolyacrylamide gel electrophoresis of human parotid salivary proteins. Electrophoresis 12, 1032-1041.

Bradway, S. D. \& Levine, M. J. (1993). Do proline-rich proteins modulate a transglutaminase catalysed mechanism of candidal adhesion? Crit Rev Oral Biol Med 4, 293-299.

Bradway, S. D., Bergey, E. J., Scannapieco, F. A., Ramasubbu, N., Zawacki, S. \& Levine, M. J. (1992). Formation of salivary-mucosal pellicle: the role of transglutaminase. Biochem J 284, 557-564.

Brassart, D., Woltz, A., Golliard, M. \& Neeser, J.-R. (1991). In vitro inhibition of adhesion of Candida albicans clinical isolates to human buccal epithelial cells by Fuc $\alpha 1 \rightarrow 2 \mathrm{Gal} \beta$-bearing complex carbohydrates. Infect Immun 59, 1605-1613.

Cannon, R. D., Nand, A. K. \& Jenkinson, H. F. (1995). Adherence of Candida albicans to human salivary components adsorbed to hydroxylapatite. Microbiology 141, 213-219.

Cleveland, D. W., Fischer, S. G., Kirschner, M. W. \& Laemmli, U. K. (1977). Peptide mapping by limited proteolysis in sodium dodecyl sulfate and analysis by gel electrophoresis. J Biol Chem 252, 1102-1106.

Edgerton, M., Scannapieco, F. A., Reddy, M. S. \& Levine, M. J. (1993). Human submandibular-sublingual saliva promotes adhesion of Candida albicans to polymethylmethacrylate. Infect Immun 61, 2644-2652.

Gibbons, R. J., Hay, D. I. \& Schlesinger, D. H. (1991). Delineation of a segment of adsorbed salivary acidic proline-rich proteins which promotes adhesion of Streptococcus gordonii to apatitic surfaces. Infect Immun 59, 2948-2954.

Gibson, J. \& Beeley, J. A. (1994). Natural and synthetic saliva: a stimulating subject. Biotechnol Genet Eng Rev 12, 39-61.

Gillece-Castro, B. L., Prakobphol, A., Burlingame, A. L., Leffler, H. \& Fisher, S. J. (1991). Structure and bacterial receptor activity of a human salivary proline-rich glycoprotein. J Biol Chem 266, 17358-17368.

Harrington, M. G. (1990). Elution of protein from gels. Methods Enzymol 182, 488-495.

Heaney, F. C., Beeley, J. A. \& McFarlane, T. W. (1992). Interaction of salivary proteins with oral streptococci. J Dent Res 71, 1973.

Hoffman, M. P. \& Haidaris, C. G. (1993). Analysis of Candida albicans adhesion to salivary mucin. Infect Immun 61, 1940-1949.

Hoffman, M. P. \& Haidaris, C. G. (1994). Identification and characterisation of a Candida albicans-binding proteoglycan secreted from rat submandibular salivary glands. Infect Immun 62, 826-836.

Holmes, A. R. \& Shepherd, M. G. (1988). Nutritional factors determine germ tube formation in Candida albicans. $J$ Med Vet Mycol 26, 127-131.

Holmes, A. R., Cannon, R. D. \& Jenkinson, H. F. (1995a). Interactions of Candida albicans with bacteria and salivary molecules in oral biofilms. J Ind Microbiol 15, 208-213.

Holmes, A. R., Gopal, P. K. \& Jenkinson, H. F. (1995b). Adherence of Candida albicans to a cell surface polysaccharide receptor on Streptococcus gordonii. Infect Immun 63, 1827-1834.

Holmes, A. R., McNab, R. \& Jenkinson, H. F. (1996). Candida albicans binding to the oral bacterium Streptococcus gordonii involves multiple adhesin-receptor interactions. Infect Immun 64, 4680-4685.

Hubbard, M. J. (1995). Calbindin $28 \mathrm{kDa}$ and calmodulin are hyperabundant in rat ductal enamel cells. Identification of the large protein phosphatase calcineurin as a principal calmodulin target and of a secretion-related role for calbindin $28 \mathrm{kDa}$. Eur $J$ Biochem 230, 68-79.

Jensen, J. L., Lamkin, M. S. \& Oppenheim, F. G. (1992). Adsorption of human salivary proteins to hydroxyapatite: a comparison between whole saliva and glandular salivary secretions. $J$ Dent Res 71, 1569-1576.

Johnsson, M., Levine, M. J. \& Nancollas, G. H. (1993). Hydroxyapatite binding domains in salivary proteins. Crit Rev Oral Biol Med 4, 371-378.

Kauffman, D., Wong, R., Bennick, A. \& Keller, P. (1982). Basic proline-rich proteins from human parotid saliva: complete covalent structure of protein IB-9 and partial structure of protein IB-6, members of a polymorphic pair. Biochemistry 21, 6558-6562.

Kauffman, D., Hofmann, T., Bennick, A. \& Keller, P. (1986). Basic proline-rich proteins from human parotid saliva: complete covalent structures of proteins IB-1 and IB-6. Biochemistry 25, 2387-2392.

Kauffman, D. L., Bennick, A., Blum, M. \& Keller, P. J. (1991). Basic proline-rich proteins from human parotid saliva: relationships of the covalent structures of ten proteins from a single individual. Biochemistry 30, 3351-3356.

Klein, D., Kern, R. M. \& Sokol, R. Z. (1995). A method for quantitation of proteins after transfer to immobilization membranes. Biochem Mol Biol Int 36, 59-66.

Laemmli, U. K. (1970). Cleavage of structural proteins during the assembly of the head of bacteriophage T4. Nature 227, 680-685.

Murray, P. A., Prakobphol, A., Lee, T., Hoover, C. I. \& Fisher, S. J. (1992). Adherence of oral streptococci to salivary glycoproteins. Infect Immun 60, 31-38.

Newman, F., Beeley, J. A., MacFarlane, T. W., Gailbraith, J. \& Buchanan, L. (1993). Salivary protein interactions with oral bacteria : an electrophoretic study. Electrophoresis 14, 1322-1327.

Odds, F. C. (1988). Candida and Candidosis, 2 nd edn. London: Baillière Tindall.

Prakobphol, A., Murray, P. A. \& Fisher, S. J. (1987). Bacterial adherence on replicas of sodium dodecyl sulfate-polyacrylamide gels. Anal Biochem 164, 5-11.

Samaranayake, L. P. (1992). Oral mycoses in HIV infection. Oral Surg Oral Med Oral Pathol 73, 171-180.

Samaranayake, L. P. \& Holmstrop, P. (1989). Oral candidiasis and human immunodeficiency virus infection. J Oral Pathol Med 18, 554-564.

Schmid, J., Voss, E. \& Soll, D. R. (1990). Computer-assisted methods for assessing strain relatedness in Candida albicans by fingerprinting with the moderately repetitive sequence $\mathrm{Ca} 3$. J Clin Microbiol 26, 1236-1243.

Schmid, J., Hunter, P. R., White, G. C., Nand, A. K. \& Cannon, R. D. (1995). Physiological traits associated with success of Candida albicans strains as commensal colonizers and pathogens. J Clin Microbiol 33, 2920-2926.

Scully, C., El-Kabir, M. \& Samaranayake, L. P. (1994). Candida and oral candidosis: a review. Crit Rev Oral Biol Med 5, 125-157.

Shannon, I. L., Prigmore, J. R. \& Chauncey, H. H. (1962). Modified Carlson-Crittenden device for the collection of parotid fluid. J Dent Res 41, 778-783.

Skerl, K. G., Segal, E., Sreevalsan, T. \& Scheld, W. M. (1984). In vitro binding of Candida albicans yeast cells to human fibronectin. Can J Microbiol 30, 221-227. 
Sönju, T., Christensen, T. B., Kornstad, L. \& Rölla, G. (1974). Electron microscopy, carbohydrate analyses and biological activities of the proteins adsorbed in two hours to tooth surfaces. Caries Res 8, 113-122.

Strömberg, N., Borén, T., Carlén, A. \& Olsson, J. (1992). Salivary receptors for GalNAc $\beta$-sensitive adherence of Actinomyces spp.: evidence for heterogeneous GalNAc $\beta$ and proline-rich protein receptor properties. Infect Immun 60, 3278-3286.
Towbin, H., Staehelin, T. \& Gordon, J. (1979). Electrophoretic transfer of proteins from polyacrylamide gels to nitrocellulose sheets : procedure and some applications. Proc Natl Acad Sci USA 76, $4350-4354$.

Received 13 August 1996; revised 1 October 1996; accepted 8 October 1996. 